\title{
The Diagnostic Role of FDG PET/CT in Patients with Fever of Unknown Origin
}

\author{
Nedeni Bilinmeyen Ateş Tanısinda FDG PET/BT
}

\author{
Nurhan Ergül', Metin Halacl, Tevfik F. Cermik2, Resat Ozaras', Sait Sagerl, Çetin Onsel', Ilhami UsluI \\ I Istanbul University Cerrahpasa Faculty of Medicine, Department of Nuclear Medicine, Istanbul, Turkey \\ 2Istanbul Education and Research Hospital, Clinic of Nuclear Medicine, Istanbul, Turkey \\ 3 Istanbul University Cerrahpasa Faculty of Medicine, Department of Infectious Diseases, Istanbul, Turkey
}

\begin{abstract}
Objective: Fever of unknown origin (FUO) is a challenge for the physician and needs use of clinical, laboratory, and imaging studies and also invasive and/or non-invasive interventions to detect the etiology. The aim of present study was to assess the role of FDG PET/CT in determining the etiology in patients with FUO.

Material and Methods: Twenty-four patients (median age 52, range 5-77 years, 6 female, 18 male) who were diagnosed with FUO were retrospectively analyzed in this study. Before the FDG PET/CT studies, none of them had a definitive reason for their diseases investigated by conventional radiological or scintigraphic methods, clinical and laboratory observations.

Results: The positive result was achieved in $19(79.2 \%)$ of 24 patients as findings of the FDG PET/CT. However, FDG PET/CT was Useful for definitive diagnosis in $12(63.2 \%)$ of 19 positive patients. Malignant diseases were determined to be the underlying cause of FUO in $5(41.6 \%)$ of 12 patients. Noninfectious inflammatory causes were detected in 2 (16.7\%) patients, infections were exhibited in $3(25 \%)$ patients, and miscellaneous diseases demonstrated in $2(16.7 \%)$ patients. In 7 patients the detected pathological uptakes on FDG PET/CT were not helpful for the definitive diagnosis. In remaining 5 patients who showed no pathological uptake in the FDG PET/CT, diagnosis could not be established by other methods, as well. The sensitivity, specificity, and positive and negative predictive values for the determination of FUO etiology were $92.3 \%, 45.4 \%, 63.1 \%$, and $100 \%$ for FDG PET/CT.
\end{abstract}

Conclusion: Our results demonstrate that FDG PET/CT seems to have considerable contribution to reveal the reason of undiagnosed patients with FUO investigated by conventional diagnostic methods, clinical and laboratory observations. (MIRT 201 1; 20: 19-25)

Key words: Fluorodeoxyglucose F18; positron-emission tomography; fever of unknown origin; diagnosis

\section{Özet}

Amaç: Nedeni bilinmeyen ateș (NBA) klinisyenler için halen tanımlanması zor bir hastalık olup klinik, laboratuvar ve görüntüleme tekniklerinin yanında birçok invaziv ve noninvaziv girișimlere gerek duyulan bir durumdur. Bu çalıșmanın amacı, NBA etyolojisini saptamada FDG PET/BT'nin yerini saptamaktı.

Gereç ve Yöntemler. FUO tanısı almıs 24 hasta (ortalama yas 52, 5-77 aralığında, 6 kadın, 18 erkek) retrospektif olarak incelendi Bulgular: Yirmi dört hastadan 19'unda (\%79.2) FDG PET/BT bulguları pozitif bulundu. Bu 19 hastadan 12'sinde (63.2) FDG PET/ BT tanıya yardımcı oldu. NBA etyolojisinde 12 hastadan 5 'inde (\%41.6) malignite saptandı. Noninfeksiyoz enflamatuar nedenler 2 hastada (16.7) tespit edilirken, 3 hastada (\%25) enfeksiyon, 2 hastada (\%16.7) az rastlanan nedenler saptandı. Yedi hastada FDG PET/BT'de saptanan patolojik

Address for Correspondence: Nurhan Ergül MD, Istanbul University, Cerrahpasa Faculty of Medicine, Department of Nuclear Medicine, Cerrahpaşa, Fatih, Istanbul, Turkey Phone: +90 2124143000 Faks: +90 2126320050 E-mail: ngozubuyukoglu@gmail.com

Received: 07.09.2010 Accepted: 29.03.2011

Molecular Imaging and Radionuclide Therapy, published by Galenos Publishing 
tutulumlar tanıya yardımcı olmadı. Patolojik tutulum görülmeyen 5 hastada diğer tanı yöntemleriyle de bir tanıya ulașılamadı. FDG PET/BT'nin NBA etyolojisini saptamadaki sensitivite, spesifite, pozitif ve negatif prediktif değerleri \%92.3, \%45.4, \%63.1, ve \%100 bulundu.

Sonuç: Bu çalıșmada FDG PET/BT'nin diğer tanı yöntemleriyle tanı alamayan NBA olgularında etyolojiyi saptamada faydalı bir yöntem olduğu gösterilmiștir. (MIRT 201 1; 20: 19-25)

Anahtar kelimeler: Fluorodeoksiglukoz F18; pozitron-emisyon tomografi; sebebi bilinmeyen ates; tanı

\section{Introduction}

The classical definition of fever of unknown origin (FUO) was made by Petersdorf and Beeson in 1961 as "a fever that is measured to be above $38.3 \mathrm{OC}$ on several occasions during a period longer than 3 weeks for which the etiology behind cannot be diagnosed at the end of at least 1 week hospital stay" (1). In 1991, Durack and Street have made two major changes on this definition which identified and separated FUO types (nosocomial FUO, neutropenic FUO, HIV-associated FUO) that require entirely different clinical approaches in diagnosis and treatment compared with the classical one; moreover, the requirement of at least 1 week hospital stay has been replaced with 3 days hospital stay or 3 outpatient visits (2). The prevalence of FUO among hospitalized adult patients is reported to be $2.9 \%$ (3). The spectrum of FUO etiology may include more than 200 diseases (2). The diseases causing FUO vary depending on geographical differences, development level of countries, and experience of the clinician (4). According to the studies conducted to date, the diseases taking part in FUO etiology and their rates are as follows: infections (21-54\%), noninfectious inflammatory causes (13-24\%), neoplasms $(6-31 \%)$, and other causes $(4-6.5 \%)(4)$. The rate of failure to reach a definitive diagnosis in patients with FUO, varies between $7-53 \%(5)$.

In patients presenting with $\mathrm{FUO}$, basic diagnostic methods are performed following detailed history and physical examination. As those methods can differ between clinics, generally the followings are employed: routine biochemical blood tests, complete blood count $(C B C)$, peripheral blood film, urinalysis, blood cultures, and chest $x$-ray (2). In some centers, abdominal USG and CT along with tuberculin skin test are applied, as well (5).

FDG PET is a valuable method for its success in demonstrating both neoplasms, and infection-inflammation foci. Currently, the contribution of FDG PET or PET/CT in FUO diagnosis has been reported to be $16-69 \%(6)$. The aim of the present study was to assess the diagnostic role of FDG PET/CT in determining the etiology in patients with FUO.

\section{Materials and Methods}

\section{Patients}

In the present study, 28 patients who have been diagnosed as FUO and referred to investigation of the etiology of the fever were retrospectively analyzed by FDG PET/CT. Because adequate clinical information could not be reached in 4 of those patients, they were excluded from the study. The remaining 24 patients $(6$ female and 18 male, median age: 52 years [range $5-77$ years]) were included in the study.

All the patients complied with the FUO criteria (a continuous or repeated fever that is measured to be above $38.3 \mathrm{OC}$ during a period longer than at least 3 weeks for which the etiology behind could not be diagnosed within 1 week of clinical investigation). None of the patients had an underlying disease that could lead to immunodeficiency. Median duration of patients' fever before PET/CT scan was 75 days (range 22 days1 year). All the patients had received basic diagnostic assessments including routine biochemical tests, $C B C$, peripheral blood film, urinalysis, blood cultures, and chest x-ray. Thoracic CT and abdominal CT had been performed in $80 \%$ and $65 \%$ of patients, and other diagnostic methods such as abdomen MRI and scintigraphic methods had been conducted in $21 \%$ and $8 \%$ of patients, respectively. In our study group, above mentioned conventional imaging methods and noninvasive laboratory tests were performed before FDG PET/CT scans, and there was not any definitive diagnosis of FUO in our patients.

\section{FDG PET/CT Imaging}

All the PET/CT scans were performed by a high-resolution PET scanner with an integrated six-slice multidetector CT (Siemens Biograph LSO HI-RES PET/CT, Illinois, USA). Prior to FDG injection, blood sugar was measured in well hydrated patients who fasted at least 4 hours before their appointment. 296-703 MBq FDG was administered intravenously to the patients with a blood sugar level below $150 \mathrm{mg} / \mathrm{dL}$. Following injection, patients were left to rest in a peaceful and comfortable room for 60 minutes in order to let FDG to complete its biodistribution throughout the body. At the end of this waiting period, bladders of the patients were emptied and they were instructed to lie down at supine position on the PET/CT scanner bed. Following noncontrast low-dose CT scan, vertex-to-toe whole body PET scan was performed. PET scans were completed with acquirement of 7-8 bed positions with 3-4 minutes of acquisition time per position from vertex-to-upper thigh. In lower extremities, PET scan was carried out with acquirement of 6-7 bed positions with 2-3 minutes of acquisition time per position from upper thigh-to-feet.

\section{Image Analysis}

PET/CT images were visually and semiquantitatively assessed by an experienced nuclear medicine physician. The 
reconstructed images were visually assessed in the standard axial, coronal, and sagittal views. The accumulation of FDG outside the physiological uptake areas was considered pathological. For semiquantitative analysis, a region of interest was carefully drawn around the site of increased FDG uptake on the subsequent 4-10 PET scan slices and the maximum standardized uptake values (SUVmax) of the lesions were calculated and used for this analysis. The SUV was calculated using the following formula: SUV=Tissue concentration $(\mathrm{Bq} / \mathrm{g}) /[$ Injected dose $(\mathrm{Bq}) /$ Body weight $(\mathrm{g})]$.

The prognosis of the disease was followed-up for 3 months after the PET/CT study by conventional diagnostic examinations and procedures. Diagnosis of patients with detected pathologies was conducted by localized detailed imaging methods, biopsies, and other invasive procedures or clinical observation aimed at the pathological findings, whereas secondary evaluations and clinical examinations were employed in other patients.

FDG PET/CT was considered to help FUO diagnosis (true positive) in cases where the pathological foci shown by PET/CT displayed consistency with the definitive diagnosis of the patients. Scans which have shown foci that were not consistent with the diagnoses (false positive), and scans where PET/CT showed no pathological foci despite determination of a foci by other methods or during the clinical follow-up (false negative) were considered to be unhelpful for the diagnosis. In cases where PET/CT was negative and no pathological focus could be determined, the result was considered as true negative.

\section{Statistical Analysis}

Conventional methods were used to generate descriptive statistics and sensitivity, specificity and positive and negative

Table 1. The patients' characteristics, FDG-PET/CT results and final diagnosis

\begin{tabular}{|c|c|c|c|c|c|c|}
\hline Pts & $\begin{array}{l}\text { Age } \\
\text { /Sex }\end{array}$ & $\begin{array}{l}\text { Duration } \\
\text { of Fever }\end{array}$ & $\begin{array}{l}\text { Imaging Studies Before } \\
\text { PET/CT (except Chest X-Ray) }\end{array}$ & $\begin{array}{l}\text { Pathology Detected } \\
\text { by PET/CT }\end{array}$ & $\begin{array}{l}\text { Established } \\
\text { Diagnosis }\end{array}$ & $\begin{array}{l}\text { bution of } \\
T \text { to Diagnosis }\end{array}$ \\
\hline 1 & $54 / \mathrm{M}$ & $6 \mathrm{~ms}$ & Abdominal US and CT & Descending colon & Colon Adeno Ca & Yes \\
\hline 2 & $40 / \mathrm{M}$ & $1 \mathrm{~m}$ & Cranial MR, Thoracic, Abdominal CT & Negative & FUO & No \\
\hline 3 & $54 / \mathrm{M}$ & $3 \mathrm{~ms}$ & $\begin{array}{l}\text { Bone scan, Abdominopelvic } \\
\text { MRI, Thoracic CT }\end{array}$ & T12 vertebra & FUO & No \\
\hline 4 & $34 / \mathrm{M}$ & $2 \mathrm{~ms}$ & $\begin{array}{l}\text { Thoracic, Abdominopelvic } \\
\mathrm{CT} \text {, Bone Marrow Biopsy }\end{array}$ & $\begin{array}{l}\text { Spleen and bone } \\
\text { marrow }\end{array}$ & FUO & No \\
\hline 5 & $39 / \mathrm{M}$ & 23 days & Thoracic, Abdominopelvic CT & Skeletal system & FUO & No \\
\hline 6 & $58 / \mathrm{M}$ & $1 \mathrm{~ms}$ & Cervical MRI, Dorsolombar MRI & Bone marrow & Lymphoma & Yes \\
\hline 7 & $77 / \mathrm{M}$ & $2 \mathrm{~ms}$ & Thoracic, Abdominal CT & Bone marrow & Lymphoma & Yes \\
\hline 8 & $75 / \mathrm{M}$ & $1 \mathrm{~m}$ & Thoracic, Abdominal CT, Bone Scan & Negative & FUO & No \\
\hline 9 & $61 / F$ & $2 \mathrm{~ms}$ & Thoracic, Abdominal CT & Big vessels & Temporal Arteritis & Yes \\
\hline 10 & $18 / F$ & $1 \mathrm{~ms}$ & Abdomen MRI & Right adrenal & Adrenal Cancer & Yes \\
\hline 11 & $57 / \mathrm{M}$ & $1 \mathrm{~ms}$ & Thoracic, Abdominal CT, Endoscopy & Bone marrow & FUO & No \\
\hline 12 & $28 / \mathrm{M}$ & 25 days & Thoracic, Abdominal CT & Right popliteal region & Thrombophlebitis & Yes \\
\hline 13 & $64 / F$ & 1 year & Abdominopelvic CT & Colon & FUO & No \\
\hline 14 & $74 / \mathrm{M}$ & $2 \mathrm{~ms}$ & Thoracic CT & Liver & Polymyalgia Rheumatica & No \\
\hline 15 & $77 / \mathrm{M}$ & $4 \mathrm{~ms}$ & Thoracic, Abdominal CT & $\begin{array}{l}\text { Lower extremities, } \\
\text { soft tissues }\end{array}$ & Nonspecific vasculitis & Yes \\
\hline 16 & $67 / F$ & $2 \mathrm{~ms}$ & Thoracic, Abdominal CT & Negative & FUO & No \\
\hline 17 & $34 / \mathrm{M}$ & $4 \mathrm{~ms}$ & Thoracic, Abdominal CT & Spleen & Babesiosis & Yes \\
\hline 18 & $74 / \mathrm{M}$ & 22 days & - & Lungs & Pneumonia & Yes \\
\hline 19 & $27 / F$ & $3 \mathrm{~ms}$ & Thoracic, Abdominal CT, Cervical US & Negative & FUO & No \\
\hline 20 & $68 / \mathrm{M}$ & $2 \mathrm{~ms}$ & Thoracic CT, Dorsolombar MRI & Negative & FUO & No \\
\hline 21 & $63 / M$ & $2 \mathrm{~ms}$ & $\begin{array}{l}\text { Thoracic, abdominal CT, } \\
\text { Tc-99 m labeled leukocyte scan }\end{array}$ & Pericardium & Pericarditis & Yes \\
\hline 22 & $58 / \mathrm{M}$ & $3 \mathrm{~ms}$ & Thoracic, Abdominal CT & Abdominal LAPs & Castleman's Disease & Yes \\
\hline 23 & $40 / F$ & $1 \mathrm{~m}$ & Thoracic, Abdominal CT & Right ovary & Lymphoma & Yes \\
\hline 24 & $5 / \mathrm{M}$ & $2 \mathrm{~ms}$ & Thoracic, Abdominal CT & Liver, pancreas & FUO & No \\
\hline
\end{tabular}

M: male, F: female, m: months, LAP: lymphadenopathy, US: ultrasound, CT: computed tomography, MRI: magnetic resonance imaging, FUO: fever of unknown origin 
predictive values were calculated based on their standard definitions.

\section{Results}

Data on demographic characteristics of the patients, duration of fever, imaging studies prior to $\mathrm{PET} / \mathrm{CT}$, nonphysiological uptakes detected with $\mathrm{PET} / \mathrm{CT}$, established definitive diagnosis, and contribution of PET/CT to diagnosis, are given in Table 1.

Pathological findings were detected by FDG PET/CT in 19 $(79.2 \%)$ of 24 patients with FUO. The definitive diagnosis found to be consistent with the foci indicative of pathological uptakes determined by FDG PET/CT in 12 (63.2\%) of 19 patients. Neoplasms were determined to be the underlying cause of FUO in $5(41.6 \%)$ of 12 patients with definitive diagnosis (Figure 1). In 2 (16.7\%) patients displayed noninfectious

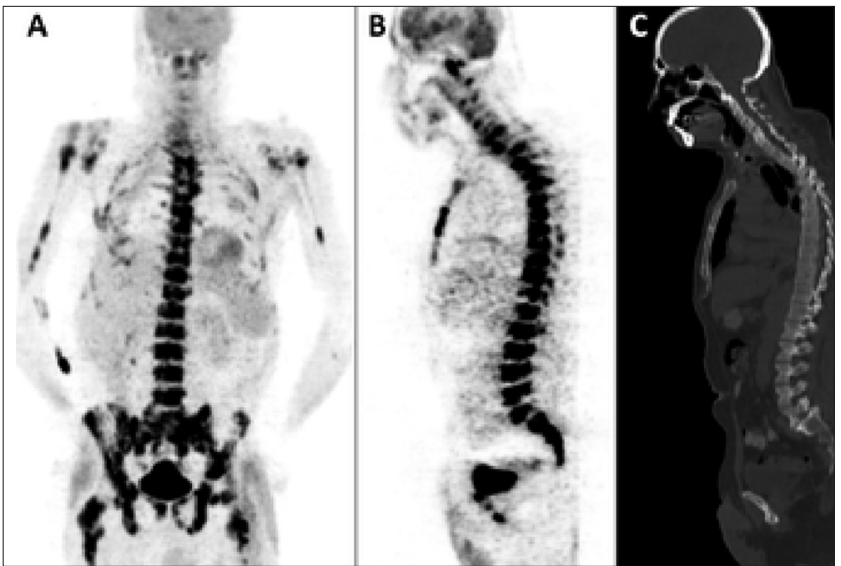

Figure 1. PET images of anterior MIP (A), sagittal PET (B) and CT(C) show involvement of bone marrow in several anatomical parts, the most prominent ones being vertebral column, pelvic bones, and proximal femur. Bone marrow biopsy revealed large B cell lymphoma

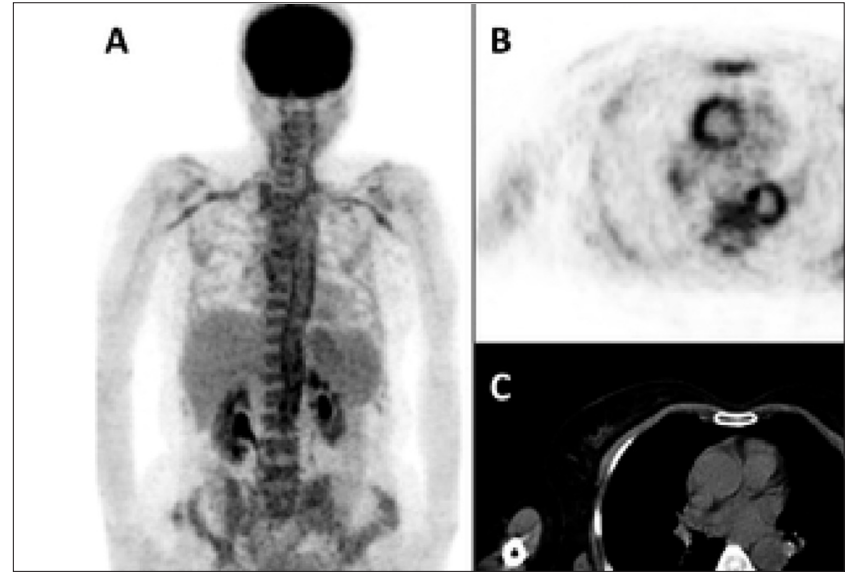

Figure 2. PET images of anterior MIP (A), transaxial PET (B) and CT (C) show involvement in large vessels (aorta, subclavian arteries, and carotid arteries). A biopsy of temporal artery revealed giant cell arteritis (temporal arteritis)

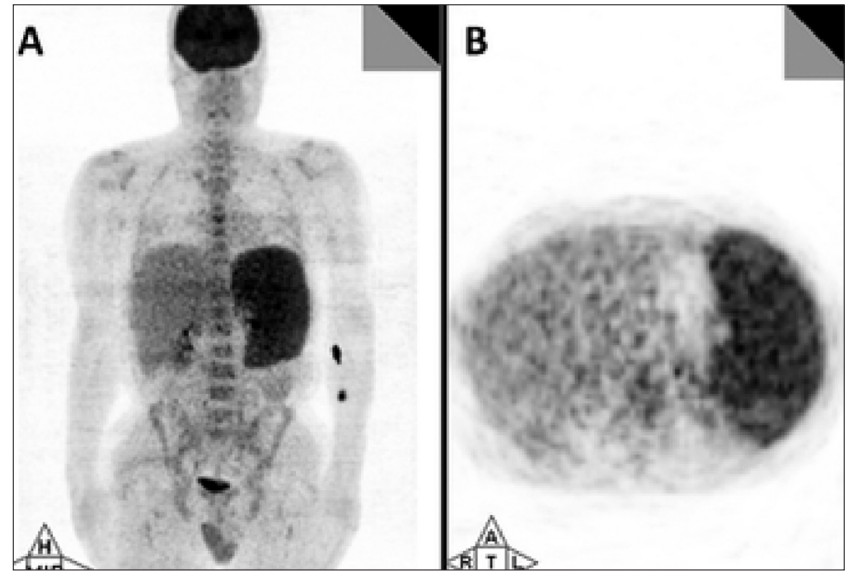

Figure 3. Anterior MIP (A) and transaxial (B) PET images show hepatosplenomegaly and a diffuse involvement of spleen. After PET/CT scan several new smears were prepared and diagnosed as having babesiosis

Table 2. The definitive diagnosis of patients with fever of unknown origin

\begin{tabular}{lccccc}
\hline Definitive Diagnosis & Patients & True positive & True negative & False positive & False negative \\
\hline NEOPLASMS & 5 & 5 & - & - & - \\
Lymphoma & 3 & 3 & - & - & - \\
Colon cancer & 1 & 1 & - & - & - \\
Adrenal cancer & 1 & 1 & - & - & - \\
INFECTIONS & 3 & 3 & - & - & - \\
Babesiosis & 1 & 1 & - & - & - \\
Pneumonia & 1 & 1 & - & - & - \\
Viral pericarditis & 1 & 1 & - & & - \\
NON-INFECTIOUS & 3 & 2 & - & - & - \\
INFLAMMATORY DiSEASES & 1 & 1 & - & - \\
Temporal arteritis & 1 & - & - & - \\
Polymyalgia rheumatica & 1 & 1 & - & - \\
Nonspecific vasculitis & 2 & 2 & - & - \\
MISCELLANEOUS & 1 & 1 & 5 & - \\
Thrombophlebitis & 1 & 1 & $\mathbf{5}$ & - \\
Castleman's disease & 11 & - & & - \\
UNDIAGNOSED & $\mathbf{2 4}$ & $\mathbf{1 2}$ & & $\mathbf{0}$ \\
TOTAL & & & & - \\
\end{tabular}


inflammatory causes (Figure 2), 3 (25.0\%) patients exhibited infections (Figure 3), and 2 (16.7\%) patients demonstrated other diseases (Table 2). In 6 patients (pts 3,4,5, 1 1, 13,24) the detected pathological uptakes were not found useful for diagnosis and reason of fever could not be established by any other methods. One patient (pt 14) who was diagnosed with polymyalgia rheumatica by biopsy, demonstrated pathological uptakes in the liver but those findings were evaluated as hematomas by MRI and these 7 patients' (36.8\%) FDG PET/CT findings were considered as false positive.

In 5 patients (pts 2,8,16,19,20) who showed no pathological uptake in the FDG PET/CT, diagnosis could not be established by other diagnostic methods, as well. Definitive diagnosis was reached in $12(50 \%)$ of 24 patients as a result of the FDG $\mathrm{PET} / \mathrm{CT}$ findings.

Definitive diagnoses were confirmed via biopsy in 4 patients (pts $6,7,9,15$ ), the verification was established by operation in 3 patients (pts 1, 10,23). Because laparoscopic biopsy did not contribute to a patient (pt 22) who exhibited abdominal hypermetabolic lympadenopathies in FDG PET/CT, laparotomy was performed and the case was diagnosed as Castleman's disease. In 5 patients, diagnosis was achieved through PET/CT findings, clinical observation, specific laboratory tests, and other imaging modalities (pts 12,14,17,18,21).

In determination of FUO etiology, FDG PET/CT demonstrated $92.3 \%$ sensitivity, $45.4 \%$ specificity, $63.1 \%$ positive predictive value, and $100 \%$ negative predictive value, respectively.

\section{Discussion}

Due to wide variety of etiology of FUO, physicians still experience difficulties in selecting and applying the diagnostic procedures in these cases. Because morphological alterations may not occur at early periods of infections and inflammatory processes, both of which constitute the bulk of the FUO etiology, the sensitivity of anatomical imaging modalities such as USG, $\mathrm{CT}$, and MRI could be low. Moreover, since these modalities only show certain parts of the body, they cannot provide information on pathological events in systemic disorders (7). The rate of failure to reach a definitive diagnosis varies between 7 $53 \%$ in the literature (5). Moreover, the rate of undiagnosed patients is reported to increase in the recent years $(2,5)$. In cases where imaging modalities are not successful and fine needle aspiration biopsies or excisional biopsies fail, exploratory laparotomy may be performed. It can be of help particularly in tuberculosis and hematological malignancies (8). Tuberculosis infection constitutes a considerable portion of FUO etiology particularly in developing countries (9).

FDG PET or PET/CT scan has been reported to be effective in the detection of malignancies as well as determination of extent of disease, treatment response and prognosis. Since the most common 3 etiologies of FUO are known to be infections, noninfectious inflammatory events and neoplasms, FDG PET scan appears to be a valuable modality in diagnosing the etiology of FUO.

In the current study, contribution of FDG PET/CT to establishment of a diagnosis in patients with $\mathrm{FUO}$ was $50 \%$. Because our study group was selected from patients who had undergone conventional imaging and laboratory methods, $50 \%$ diagnostic ratio of FDG PET/CT could be quite reasonable. The most common FUO etiology is infections followed by neoplasms and noninfectious inflammatory events with varying rates $(2,3,4,9)$. However, in the present study, neoplasms are found to be more common than infectious diseases. The underlying etiologies found in true positive FDG PET/CT scans were malignant diseases in $41.6 \%$, infections in $25.0 \%$, noninfectious inflammatory diseases $16.7 \%$, and other reasons in $16.7 \%$. This result is probably due to elimination of tuberculosis and brucellosis by applying specific diagnostic tests at the beginning. Similar to the previous studies in the literature, lymphomas have been found to be the most common malignant disease among patients with neoplasms in our study group $(4,10)$.

In previous studies which utilized FDG PET for diagnosis of FUO, contribution of FDG PET to the diagnosis has been reported to be between $16-69 \%(6,7,11,12,13,14,15,16,17)$. Furthermore, in the current study, the sensitivity, specificity, positive predictive value, and negative predictive value of FDG PET/CT were found to be $92.3 \%, 45.4 \%, 63.1 \%$, and $100 \%$, respectively. Relatively low results for specificity and positive predictive value are associated with the high number of false positive results $(n=7)$.

The study of Lorenzen et al (12) is one of the first studies using FDG PET in diagnosis of FUO and they found the contribution of FDG PET to establishment of diagnosis in a group of 16 patients, as $69 \%$. They noted the absence of a pathological focus which could be the underlying cause for fever among patients with negative FDG PET results, and reported a high negative predictive value for FDG PET (12). In the present study, similarly, no diagnosis could be reached by other diagnostic methods in 5 patients who also did not demonstrate pathological uptake in the FDG PET/CT.

Bleeker-Rovers and colleagues (13) retrospectively studied the contribution of FDG PET to the diagnostic process of patients in whom FUO or suspicious infection and inflammation foci were investigated. While diagnosis could be reached in $46 \%$ of 35 patients with FUO, they found the contribution of FDG PET to diagnosis, as $37 \%$. They reported sensitivity, specificity, positive predictive value, and negative predictive value of FDG PET as $93 \%, 90 \%$, $87 \%$, $95 \%$, respectively (13). Another study by the same group evaluated the place of FDG PET in FUO diagnosis prospectively. Diagnosis was reached in $50 \%$ of 70 patients and the contribution of FDG PET to the diagnosis was reported to be $33 \%$. The sensitivity, specificity, positive predictive value, and negative predictive value of FDG PET was found $88 \%, 77 \%, 70 \%$, and $92 \%$, 
respectively. In the same study, abdominal and thoracic $\mathrm{CT}$ s were performed in a subgroup of 43 patients. The positive and negative predictive values of abdominal and thoracic $\mathrm{CT}$ were $48 \%$ and $86 \%$, respectively (14).

Buysschaert et al conducted a study on 74 patients with FUO and succeeded to diagnose 53 of them and found the contribution of FDG PET as $26 \%$ (15). Jaruskova et al reported contribution of FDG PET or PET/CT to the diagnosis as $36 \%$ among 118 patients (94 had FUO) with prolonged fever (7). Federici et al performed a study on 14 patients $(10$ with FUO and 4 with prolonged inflammatory syndrome) and reported the contribution of FDG PET to the diagnosis as $50 \%(6)$.

There are also studies which compare the FDG PET and nuclear medicine methods in FUO diagnosis $(11,16,17)$. Meller et al (11) performed a study and found the contribution of FDG PET to the diagnosis as $55 \%$ which was performed by a double-head coincidence camera in 20 patients with FUO. The sensitivity, specificity, positive and negative predictive values of FDG PET were found to be $81 \%, 86 \%, 92 \%$, and $75 \%$, respectively. The sensitivity, specificity, positive and negative predictive values of $\mathrm{Ga} 67$ in this study were reported to be $67 \%, 78 \%, 75 \%$, and $70 \%$, respectively (11). Because of disadvantages of $\mathrm{Ga} 67$ scan such as high radiation dose, long duration of procedure and evaluation, low spatial resolution, and low sensitivity, specificity, positive and negative predictive values, FDG PET is a more valuable method $(11,18,19)$.

Giant cell arteritis and Takayasu arteritis constitute $17 \%$ of all FUO causes. FDG PET has been reported to be superior to other imaging modalities in detection of vasculitis $(11,6,16)$. FDG uptake has been shown in cases of giant cell arteritis, polymyalgia rheumatica, Takayasu arteritis, peritonitis associated with Wegener granulomatosis, and infectious vasculitis (20). The sensitivity and specificity of FDG PET in detection of vasculitis have been reported to be $77-100 \%$ and $89-100 \%$, respectively (21). CT and MRI are employed for diagnosis of Takayasu arteritis, however, FDG PET has been found to be more effective especially for lesions of early stage (22). In the current study, vasculitis was diagnosed in all the 3 patients with noninfectious inflammatory causes.

The design of the present study had some limitations. First, there was a lack of the reason of false positive results of FDG $\mathrm{PET} / \mathrm{CT}$ in six patients in follow-up period. Second, we consider the small number of patients with $\mathrm{FUO}$ as a deficiency of this report.

In conclusion, the results of the present study demonstrate that FDG PET/CT seems to have considerable contribution to reveal the reason of undiagnosed patients with FUO investigated by conventional diagnostic methods, clinical and laboratory tests. Therefore, routine use of FDG PET/CT in assessing FUO is well justified.

\section{References}

1. Petersdorf RG, Beeson PB. Fever of unexplained origin: report on 100 cases. Medicine (Baltimore). 1961;40:1-30.

2. Gaeta GB, Fusco FM, Nardiello $S$. Fever of unknown origin: a systematic review of the literature for 1995-2004. Nucl Med Commun 2006;27:205-211.

3. Mourad O, Palda V, Detsky AS. A comprehensive evidence-based approach to fever of unknown origin. Arch Intern Med 2003; 163:545-551.

4. Tabak F, Mert A, Celik AD, Ozaras R, Altiparmak MR, Ozturk R, Aktuglu $Y$. Fever of unknown origin in Turkey. Infection 2003;31:417-420.

5. Bleeker-Rovers CP, Vos FJ, de Kleijn EM, Mudde AH, Dofferhoff TS, Richter C, Smilde TJ, Krabbe PF, Oyen WJ, van der Meer JW. A prospective multicenter study on fever of unknown origin: the yield of a structured diagnostic protocol. Medicine (Baltimore) 2007;86:26-38.

6. Federici L, Blondet C, Imperiale A, Sibilia J, Pasquali JL, Pflumio F, Goichot B, Blaison G, Weber JC, Christmann D,Constantinesco A, Andrès E. Value of F1 8 FDG PET/CT in patients with fever of unknown origin and unexplained prolonged inflammatory syndrome: a single centre analysis experience. Int J Clin Pract 2010;64:55-60.

7. Jaruskova M, Belohlavek O. Role of FDG PET and PET/CT in the diagnosis of prolonged febrile states. Eur J Nucl Med Mol Imaging 2006;33:913-918.

8. Ozaras R, Celik AD, Zengin K, Mert A, OzturkK R, Cicek Y, Tabak E. Is laparotomy necessary in the diagnosis of fever of unknown origin? Acta Chir Belg. 2005;105:89-92.

9. Onal IK, Cankurtaran M, Cakar M, Halil M, Ulger Z, Doğu BB, Uzun $\mathrm{O}$, Unal S, Arioğul S. Fever of unknown origin: what is remarkable in the elderly in a developing country? J Infect 2006;52:399-404.

10. Krem MM, Pan L, Blinder MA. F18 FDG PET-facilitated diagnosis of lymphoma presenting with fever of unknown origin and cold agglutination. Leuk Lymphoma. 2007;48:619-622.

11. Meller J, Altenvoerde G, Munzel U, Jauho A, Behe M, Gratz S, Luig $H$, Becker W. Fever of unknown origin: prospective comparison of [18F]FDG imaging with a double-head coincidence camera and gallium-67 citrate SPET. Eur J Nucl Med 2000;27:1617-1625.

12. Lorenzen J, Buchert R, Bohuslavizki KH. Value of FDG PET in patients with fever of unknown origin. Nucl Med Commun 2001;22:779-783.

13. Bleeker-Rovers CP, de Kleijn EM, Corstens FH, van der Meer JW, Oyen WJ. Clinical value of FDG PET in patients with fever of unknown origin and patients suspected of focal infection or inflammation. Eur J Nucl Med Mol Imaging. 2004;31:29-37.

14. Bleeker-Rovers CP, Vos FJ, Mudde AH, Dofferhoff AS, de Geus-Oei LF, Rijnders AJ, Krabbe PF, Corstens FH, van der Meer JW, Oyen WJ. A prospective multi-centre study of the value of FDG PET as part of a structured diagnostic protocol in patients with fever of unknown origin. Eur J Nucl Med Mol Imaging 2007;34:694-703.

15. Buysschaert I, Vanderschueren S, Blockmans D, Mortelmans L, Knockaert D. Contribution of (18) fluoro-deoxyglucose positron emission tomography to the work-up of patients with fever of unknown origin. Eur J Intern Med 2004;15:151-156.

16. Blockmans D, Knockaert D, Maes A, De Caestecker J, Stroobants S, Bobbaers H, Mortelmans L. Clinical value of [(18)F]fluoro-deoxyglucose positron emission tomography for patients with fever of unknown origin. Clin Infect Dis.2001;32:191-196.

17. Kjaer A, Lebech AM, Eigtved A, Høigaard L. Fever of unknown origin: prospective comparison of diagnostic value of F 18 FDG PET and 111 In-granulocyte scintigraphy. Eur J Nucl Med Mol Imaging 2004;31:622-626.

18. Peters $A M$. Nuclear medicine imaging in fever of unknown origin. $Q$ J Nucl Med 1999;43:61-73. 
19. Meller J, Ivancevic V, Conrad M, Gratz S, Munz DL, Becker W. Clinical value of immunoscintigraphy in patients with fever of unknown origin. J Nucl Med 1998;39:1248-1253.

20. Bleeker-Rovers CP, Bredie SJ, van der Meer JW, Corstens FH, Oyen WJ. F 18-fluorodeoxyglucose positron emission tomography in diagnosis and follow-up of patients with different types of vasculitis. Neth J Med 2003;61:323-329.
21. Otsuka H, Morita N, Yamashita K, Nishitani H. FDG PET/CT for diagnosis and follow-up of vasculitis. J Med Invest 2007;54:345-349.

22. Umekita K, Takajo I, Miyauchi S, Tsurumura K, Ueno S, Kusumoto N, Kai Y, Kuroki M, Sasaki T, Okayama A. [18F] fluorodeoxyglucose positron emission tomography is a useful tool to diagnose the early stage of Takayasu's arteritis and to evaluate the activity of the disease. Mod Rheumatol. 2006;16:243-247. 